\title{
IAMJ
}

INTERNATIONAL AYURVEDIC MEDICAL JOURNAL

\section{PREVENTIVE AND CURATIVE ASPECT OF DHUMNASYA (NASAL INSUFFLATION OF MEDICATED SMOKE)}

\author{
Tanuja Mehta ${ }^{1}$, Uttam Kumar Sharma ${ }^{2}$, Bhawana Mittal ${ }^{3}$, Shikha Pandey ${ }^{4}$ \\ ${ }^{1}$ PG Scholar $2^{\text {nd }}$ Year, Department of Panchkarma, UAU Gurukul Campus, Haridwar, Uttarakhand, India \\ ${ }^{2}$ Professor and Head, Department of Panchkarma, UAU Gurukul Campus, Haridwar, Uttarakhand, India \\ ${ }^{3}$ Assistant Professor, Department of Agadtantra, UAU Gurukul Campus, Haridwar, Uttarakhand, India \\ ${ }^{4}$ Assistant Professor, Department of Panchkarma, UAU Gurukul Campus, Haridwar, Uttarakhand, India
}

Corresponding Author: tanuja16oct@gmail.com

\section{https://doi.org/10.46607/iamj14p5062021}

(Published online: September 2021)

Open Access

(C) International Ayurvedic Medical Journal, India 2021

Article Received: 01/09/2021 - Peer Reviewed: 11/09/2021 - Accepted for Publication: 12/09/2021

Check for updates

\begin{abstract}
Background- Panchkarma is a group of procedures known for its preventive, promotive, prophylactic and rejuvenating properties as well as radicle cure. Nasya is one of the Panchkarma treatments. Among the various forms of Nasya, Dhumnasya is a very effective type of Nasya which has further been classified into different types based on various potency of herbs with their respective properties. Aim and Objective: To find out the role of Dhumnasya in the preventive and curative aspects. Material and Methods: Classics of Ayurveda having references regarding Nasya, Modern literature, published articles in peer-reviewed journals, published books and subject-related material available online have been screened, compiled, organized and described systematically. Result: In Dhumnasya medicinal herbs with other constituents are burnt in such an effective manner to produce a medicated fume containing volatile phytochemical of herbs, which when inhaled through nasal route exerts their efficient role in both prevention and treatment of various forms of disease both at a local and systemic level. Conclusion: In this review article, it has been tried to focus on the preventive and curative aspect of Dhumnasya so to help to address issues related to poor bioavailability, slow absorption, drug degradation and adverse event in the GIT tract and avoid the first-pass metabolism in the liver and discover the advantage of smoke based therapies as rapid delivery to the brain, more efficient pulmonary absorption and become the suitable substitute for the oral and parental administration.
\end{abstract}

Keywords: Panchkarma, Dhumnasya, Nasya, Medicated smoke. 


\section{INTRODUCTION}

Insufflation means is the act of blowing something such as gas, powder, vapour, into the body cavity. ${ }^{1} \mathrm{Na}-$ sal insufflation or inhalation involves the local application of the drug to the mucous membrane of the nose to achieve a local or systemic action. ${ }^{2}$ Administration of drug via nasal route is the novel type of drug delivery known as a suitable substitute for oral and parenteral administration. In Ayurveda, Panchkarma therapy is used for the maintenance of health and eradication of diseases from their root and Nasya Karma is one among them which is unique in the action of elimination of doshas from the organs situated above the clavicle by administration of various medicated formulations either in the form of ghee, oil, powder, liquid or smoke through nostrils and thus, Nasya Karma also acts as a route of administration of drugs. Since ancient times Acharyas are very well known the importance and effectiveness of this route as they said that Nasa hi shirsodwaram. ${ }^{3}$ The word Nasya is derived from "Nasa" Dhatu, which conveys the meaning of 'Gati'. Here the Gati is towards the internal structures mainly to head through the nose.

There are various types of Nasya is mentioned in the classics based on the use of a different type of Ayurvedic Kalpana (preparations) of Dravya: - Choorna, Kalka, Ksheera, Sneha, Mamsa, Majja, Vasa, Dhum, Madya. The use of these different substances depends on the individual disease, the level of disease and to what extent effect should be needed. According to different forms of drvaya, the potency of the drug gradually changes. ${ }^{4}$
Among them is Dhumnasya which is described by Acharya Charaka ${ }^{5}$ where inhalation of medicated fumes is taken by the nasal route and eliminated by the oral route is done. All through time, humans have used the smoke of medicinal plants to cure illness. The most frequent medical indications for medicinal smoke are pulmonary $(23.5 \%)$, neurological $(21.8 \%)$ and dermatological $(8.1 \%)$. Inhalation is typically used in the treatment of pulmonary and neurological disorders which accounts for $71.5 \%$ of indications for administrating medicinal smoke. ${ }^{6,7}$

\section{CONCEPT OF DHUMNASYA IN CLASSICS-}

Nasya is categorized into many types according to different Acharyas. In the present day, the Nasal administration is in many forms like Marsha, Pratimarsha, Pradhamana, Avapida, Dhum and Nasapana. Dhum Nasya is described only by Acharya Charaka as a type of Nasya. Acharya Shushutra has not described it while describing Nasya, although in chapter Dhum Nasya kavalgraha chikitsa have described Dhumpana instead of Dhumnasya.

'Dhum' Meaning Vapor, Mist, Smoke. 'Pana' meaning inhalation of medicated smoke through mouth or nose and releasing it only through the mouth as per the protocol mentioned in Ayurvedic Classics. In Ayurveda, proper medicated Fume inhalation therapy has been not explained but the process of Dhumpana and Nasya may be analogue to some extend. Thus, Dhumpana can also be considered under the broad umbrella of Nasya.

\section{TYPES OF DHUMNASYA AND THEIR PREVENTIVE OR CURATIVE ASPECT- ${ }^{8,9,10}$}

\begin{tabular}{|c|c|c|c|c|}
\hline Type & $\begin{array}{l}\text { Explanation of San- } \\
\text { skrit terminology }\end{array}$ & Effect / Properties & Herbs & $\begin{array}{l}\text { Therapeutic and Preventive } \\
\text { indication }\end{array}$ \\
\hline Prayogika & $\begin{array}{l}\text { Sanskrit word } \\
\text { Prayog means ap- } \\
\text { plication, use daily } \\
\text { as a part of Din- } \\
\text { charya (daily regi- } \\
\text { men) or for specific } \\
\text { symptoms }\end{array}$ & $\begin{array}{l}\text { - As a part of Daily } \\
\text { routine regime/ ther- } \\
\text { apeutic use. } \\
\text { - Drugs with moderate } \\
\text { action strength. } \\
\text { - Soothing, balancing } \\
\text { of kapha and Vata }\end{array}$ & $\begin{array}{l}\text { Shallaki, black cumin } \\
\text { (Prithvika or Nigella Sa- } \\
\text { tiva } \\
\text { Linn), sugar (Sharkara, } \\
\text { made from sugarcane), } \\
\text { bark } \\
\text { of Indian banyan } \\
\text { (Nyagrodha or ficus ben- } \\
\text { galensis }\end{array}$ & $\begin{array}{l}\text { Helpful in the strengthen- } \\
\text { ing of the scalp hair, skull } \\
\text { bones, sense organs and } \\
\text { voice. }\end{array}$ \\
\hline
\end{tabular}




\begin{tabular}{|c|c|c|c|c|}
\hline & & & $\begin{array}{l}\text { Linn), Indian fig tree } \\
\text { (Udumbara or Ficus Rac- } \\
\text { emosa } \\
\text { Linn), sacred fig (Ashvat- } \\
\text { tha or ficus religiosa } \\
\text { Linn), } \\
\text { mountain fig (Plaksha or } \\
\text { Ficus locor), lodh tree } \\
\text { (Lodhra or Symplocos } \\
\text { Racemosa), Sugar, lico- } \\
\text { rice } \\
\text { (Madhuka or Glycyrrhiza } \\
\text { glabra), }\end{array}$ & \\
\hline Snaihik & $\begin{array}{l}\text { Sanskrit word } \\
\text { Sneha } \\
\text { means oil and } \\
\text { Snaihika } \\
\text { means that which } \\
\text { includes the fat-oily } \\
\text { substance as a base }\end{array}$ & $\begin{array}{l}\text { - Lubricating pallia- } \\
\text { tive soothes respira- } \\
\text { tory passages of } \\
\text { healthy, normal per- } \\
\text { son alleviates dry- } \\
\text { ness and irritation in } \\
\text { respiratory passages. } \\
\text { Drugs with mild ac- } \\
\text { tion strength. } \\
\text { Relieve dryness of } \\
\text { vata }\end{array}$ & $\begin{array}{l}\text { Masha (Black gram), Oil } \\
\text { obtained from fruits and } \\
\text { pith of trees, fat, marrow, } \\
\text { muscle-fat, and ghee } \\
\text { (butterfat), white dammar } \\
\text { (Sarjarasa or vateria } \\
\text { indica Linn). nutgrass } \\
\text { (Musta or cyperus } \\
\text { rotundus), stone flower } \\
\text { (Shaileya or Permellia } \\
\text { perforta) }\end{array}$ & $\begin{array}{l}\text { The pacification of Vata is } \\
\text { done by Snigdha Guna and } \\
\text { Uplepa Karma. } \\
\text { This type of Dhumpana is } \\
\text { prescribed in Vataroga, } \\
\text { Vatika Shirahshoola, Dan- } \\
\text { taharsha, Vataja Kasa, } \\
\text { Vaiswarya (hoarseness of } \\
\text { voice). }\end{array}$ \\
\hline Vairechanika & $\begin{array}{l}\text { Virechana means to } \\
\text { expel out } \\
\text { Vairechanic means } \\
\text { Expulsive-expels } \\
\text { the } \\
\text { excretory=waste } \\
\text { material }\end{array}$ & $\begin{array}{l}\text { Especially in dis- } \\
\text { eases of head due to } \\
\text { increased } \\
\text { Kaphadosha } \\
\text { - Drugs of strong ac- } \\
\text { tion, reduce exces- } \\
\text { sive Kapha, }\end{array}$ & $\begin{array}{l}\text { Shveta (white variety of } \\
\text { Clitoria ternatea Linn), } \\
\text { Jyotishmati (Celastrus } \\
\text { paniculatus Wild), } \\
\text { Orpiment, regular and } \\
\text { other varieties with fra- } \\
\text { grant } \\
\text { properties such as Patra- } \\
\text { Cinnamomum tamala, } \\
\text { Agaru (Aquilaria aga- } \\
\text { locha Roxb), Turmeric, } \\
\text { Manashila (Arsenic sul- } \\
\text { phide), Laksha (Coccus } \\
\text { lacca), Triphala (Termi- } \\
\text { nalia chebula, Termi- } \\
\text { nalia } \\
\text { Belerica, indian goose- } \\
\text { berries) }\end{array}$ & $\begin{array}{l}\text { It works with its Ruksha, } \\
\text { Tikshana, Ushna and Vi- } \\
\text { shada properties. } \\
\text { This type of Dhumpana is } \\
\text { prescribed in Kapha pre- } \\
\text { dominant conditions. eg. } \\
\text { Kaphaja Shirashoola, Kar- } \\
\text { nakandu, Kaphaja Sar- } \\
\text { vasara, Kaphaja Aush- } \\
\text { tharoga, Adhimansa, } \\
\text { Jvara, Kushtha, Santar- } \\
\text { panottha disease, Murchha }\end{array}$ \\
\hline Kasahari & $\begin{array}{l}\text { Kas } a=\text { Ayurvedic } \\
\text { name of } \\
\text { the disease can be } \\
\text { referred to disease } \\
\text { Cough }\end{array}$ & $\begin{array}{l}\text { Antitussive-Thera- } \\
\text { peutic smoking for } \\
\text { treatment of kasa } \\
\text { Help in the correc- } \\
\text { tion of vata, kapha. }\end{array}$ & $\begin{array}{l}\text { Sulphates of Arsenic } \\
\text { (Haratal and Manashila) } \\
\text { licorice (Madhuka or } \\
\text { Glycyrrhiza glabra) } \\
\text { spikenard (Mamsi or Nar- } \\
\text { dostachys jatamansi), nut }\end{array}$ & $\begin{array}{l}\text { In Vata-Kaphaja Kasa } \\
\text { when it is associated with } \\
\text { Pratishyaya and Shi- } \\
\text { rashool. It is also indicated } \\
\text { in the treatment of Kaphaja } \\
\text { Kasa. Kshataja Kasa, it }\end{array}$ \\
\hline
\end{tabular}




\begin{tabular}{|c|c|c|c|c|}
\hline & & $\begin{array}{l}\text { Ideally, to be con- } \\
\text { sumed while eating } \\
\text { the food. }\end{array}$ & $\begin{array}{l}\text { grass (Musta or Cyperus } \\
\text { rotundus), etc. }\end{array}$ & $\begin{array}{l}\text { removes the aggravated } \\
\text { Kapha Dosha from the } \\
\text { chest and relieves the } \\
\text { coughing. }\end{array}$ \\
\hline Vamaneeya & $\begin{array}{l}\text { Vaman means } \\
\text { vomiting, } \\
\text { Vamaneeya vomit } \\
\text { inducing }\end{array}$ & $\begin{array}{l}\text { - Emetic -It is used for } \\
\text { inducing vomiting. } \\
\text { Elimination of ex- } \\
\text { cess Kaphadosh } \\
\text { Should be given after } \\
\text { the person has filled } \\
\text { the stomach full of } \\
\text { thick gruel made } \\
\text { from sesame and } \\
\text { rice. }\end{array}$ & $\begin{array}{l}\text { horns or hairs of animals } \\
\text { like cows, etc. }\end{array}$ & $\begin{array}{l}\text { It is prescribed when accu- } \\
\text { mulated Shleshma has } \\
\text { filled the chest and throat. } \\
\text { This might be invented for } \\
\text { Sukumara people. By in- } \\
\text { haling the smoke, it may } \\
\text { stimulate the centre which } \\
\text { is responsible for emesis } \\
\text { and induces Chardana and } \\
\text { removes Kapha Dosha. }\end{array}$ \\
\hline Vrandhupan & $\begin{array}{l}\text { Medicated fumiga- } \\
\text { tion }\end{array}$ & $\begin{array}{l}\text { To clean the wound } \\
\text { and reduce pus for- } \\
\text { mation. }\end{array}$ & Nimbavachadi & \\
\hline
\end{tabular}

DHUM NETRA AND DHUM VARTI (DHUM INSTRUMENT AND DHUM-STICK) (Ca. Su. 5/2125)

Smoking of the medicinal smoke using a dried roll/wick made from a paste of herbs, (which can be referred to as Dhum-stick,) with the help of special apparatus, (which can be referred to as 'Dhum-instrument') in a systematic, and scientific manner. The smoking sticks (Ayurvedic nomenclature Dhumvarti) are made up of essential herbs. The 7 to 8 inches long medicated stick is useful for - A piece of Shara Kanda (stick of a type of grass name Saccharum munja), 10 to 11 inches' length is soaked for day and night in water. It is wrapped with silk cloth for 7 to 8 inches in length and then coated with the paste of prescribed herbs. It is allowed to dry up in shade and then Shara Kanda is removed. Methods of preparation of Dhumnetra are variable according to the types of Dhumnasya. According to Aacharya Charaka shape of Dhumnetra is Riju (unbent), trikoshfalit (three rounds in it) and kolasthiagrprmanitum (like the seed of jujube fruit pass through its anterior orifice).

BENEFITS OF DHUM NETRA- (Ca. Su. 5/51-52)

In proper dose (Matra) and duration (Kala) when Dhumnetra has used the fumes have to travel a distance (Duradavinirgata), it has to pass through the chambers (Parva Chachinna Nasi Tanu Krita) which reduces the intensity of fumes and thus the organs are protected (Naindriya Badhate).

\section{DHUMNETRA ACCORDING TO TYPE OF DHUM BY ACHARYA SUSHRUTA-}

\begin{tabular}{|l|l|l|l|}
\hline Type of Dhum & $\begin{array}{l}\text { Size of the anterior orifice } \\
\text { (agrapraman) }\end{array}$ & $\begin{array}{l}\text { Route } \\
\text { Dhumpana }\end{array}$ & Samyak yoga Lakshana \\
\hline Prayogik & Kolasthi & Nose & Doshadarshanat \\
\hline Snaihika & Kolasthi & Nose_+Mouth & Till lacrimation \\
\hline Vairechanika & Kalaychidra & Nose & 3-4 times \\
\hline Kasgana & Kolasthi & Mouth & Grasantre \\
\hline Vamaniya & Kolasthi & Mouth & Tiltandulyavagu pitten \\
\hline Vrandhupan & Kulathchidra & Vran & Vednaupsaman, Vranvesdhye, Sravsaman \\
\hline
\end{tabular}


PRAMANA OF DHUM NETRA ACCORDING TO DIFFERENT ACHARYA'S-

\begin{tabular}{|l|l|l|l|l|}
\hline Type of Dhum & Charak & Sushruta & Astang Sangrha & Sharangdhar \\
\hline Prayogik & 36 Angul (one angul $1.95 \mathrm{~cm}$ or 0.76 inch) & 48 Angul & 40 Angul & 40 Angul \\
\hline Snaihika & 32 Angul & 32 Angul & 32 Angul & 32 Angul \\
\hline Vairechanika & 24 Angul & 24 Angul & 24 Angul & 24 Angul \\
\hline Kasghana & & 16 Angul & $8 / 10$ Angul & 16Angul \\
\hline Vamaniya & & 16 Angul & 10Angul & 10Angul \\
\hline Varndhupana & & 8 Angul & 8Angul & 10Angul \\
\hline
\end{tabular}

\section{ALTERNATIVE DHUM INSTRUMENT FOR IN- TAKE OF DHUMNASYA-}

(Ah. Su. 21/22)

According to Acharya Vagbhata an alternative method of Dhum Nasya can be used to prepare Sharavasamputa (two clay pots fixed with each other containing burning Varti) with a Nadi (pipe) of eight or ten Angul ( 6-7.5 inches). Through this pipe, fumes are inhaled. AGE OF DHUMNASYA ADMINISTRATION-

(Sh. Ut. 9/9) (Ba. Pa. Pu. Ka. 9)

Dhum should be administrated in individuals above 12 years of age to below 80 years.

DHUMNASYA KALA- (Ca. Su. 5/33-35)

Acharya Charaka described eight kala for Prayogika Dhum in which there is deranged vata and kapha like, after- Snanana (bathing), bhuktawa (meal), samullekha (vomiting), kshuthawa (sneezing), dantanighrishya (toothbrushing), nasya, anjana (collyrium), nidrante (waking from sleep)

\section{ADVANTAGES OF DHUM-}

Administration of Dhum provides balama bhavati chaadhikama shiro, ruha, kapala, indriya and swara (strength to organs of head, hairs, scalp, sense organs and voice) and prevents disorders of Vata and Kapha derangement.

INDICATION OF DHUM- (Ch.Su. 5/46)

In disease of Shiro, Ghrana, Akshi.

CONTRAINDICATION OF DHUM- (Su. Ch. 40/11)

According to Acharaya Sushruta who are suffering from bhaya (fearful), Panduroga (Anaemia), Chardi (vomiting), Udara roga, Udavarta, Bala (children), Vriddha (aged), and in Alpa Kapaha conditions are contraindicated for Dhumnasya.
ADMINISTRATION OF DHUM- (Ch. Su. 5/47-49) According to Acharya Charaka individuals should sit in Rijuuanga Chakshu and Cheta (straight posture, eyes and concentrated mind). Three courses of puff are inhaled from each nostril in disorders of the nose and with the mouth in the disorder of the throat. Precaution must be taken while exhaling the fumes it must be exhaled from the mouth to prevent harm to the ocular path. Acharya Shushutra directed which inhaled route of medicated fumes should be chosen for different types of Dhumnasya like Prayogik and Vairachanika Dhum is administered from nostril, Snaihika is administered from the nasal and oral cavity, Vamaniya and Kasahara Dhum is administered from the oral cavity. Acharya Sharagdhar added external use of dhum in the wound to ease the process of rapid healing and creates a disinfected environment for it. (Sh. Ut .9/11-14) SYMPTOMS OF PROPER ADMINISTRATION OF DHUM-

There is cleanliness in the chest, throat, oral and nasal cavity, lightness in the body and Dosha are removed. There is thinning of Kapha. (Ch. Su. 5/ 52-53)

\section{DISCUSSION-1 1, 12,13,14}

The study reflects that all the classical texts and commentaries reflect a similar approach in the application of Dhumnasya. The description of instruments, types, doses, time slots, and herbs is more or less similar with additional information provided in the relevant part of it by each author.

\section{MEDICATED SMOKE-}

The smoke produced by fumigating ingredients at high temperatures is considered to be a simple way of administrating a drug that can exhibit rapid pharmacological activity when inhaled. The medicated herbs, 
guggulu, ghrita etc used in the preparation of various types of dhum varti are vaporised in fumigation and enter the body through the nasal route by inhalation from where they reach the brain followed by lungs and exerts their curative aspect in their respective target's organs. Chemically, smoke is a gaseous product of incomplete combustion of organic substances and is chiefly made up of suspended particles of unburnt carbon, which settle as soot (The Encyclopedia Americana, 1963). Thus, with the major components in smoke being carbon, there is a high probability that this carbon is present in nano form and also that this carbon nanomaterial may be functionalized with the active components contained in these medicinal smokes and thus play a role in the medicinal property exhibited by the medicinal smoke.

The procedure of Ayurvedic Dhumnasya shows a predominance of fire and air elements combined, both of them having subtle, microscopic and all-pervading quality-which refers to the Ayurvedic term 'Sooksma'. This quality in the context of Dhumnasya helps in rapid delivery and spread of medicines everywhere into all the recess and corners of the head and neck region, which includes numerous channels; it opens and enters the smallest channels, with Ushna and Tikshna Guna liquefies and eliminates the Dosha from their nearer routes. The gases are absorbed in blood by pressure difference and greater surface area in the lung. MEDICATED SMOKE AND ITS PREVENTIVE ACTION

In the preventive mode, Vrandhupan type of Dhumnasya given by Acharaya sharangdhar in which herbs possess antimicrobial, antifungal and antibacterial properties are used can be considered as an effective way to nullify the spread of airborne infection by showing their inhibitory nature on microbial growth on wound place.

In traditional healing, the burning of selected indigenous medicinal plants and the inhalation of the liberated smoke are widely accepted and a practised route of administration. These results suggest that the combustion process produces an 'extract' with superior antimicrobial activity and provides in vitro evidence for inhalation of medicinal smoke as an efficient mode of administration in traditional healing.

Diseases that are caused by pathogens comes under airborne diseases which travels over a particular time and distance in the form of small particles. They may be viruses, bacteria or fungi. It may spread through breathing, talking, sneezing, coughing, etc which generate droplets in the air Dhumnasya is an example of drug delivery where medicated substances like herbal drugs, mineral and plant origin having properties of anti-inflammatory, antipyretics, antiseptic used and burnt in a specific manner to make a Dhum which inhaled through the nasal route (Nasya), most of these dravyas are Agni and Vayu Pradhan i.e. Volatile which helps to avoid settling down of pathogens in the respiratory tract. Hence due to its advantages like easy administration, potential to penetrate the blood-brain barrier, higher bioavailability its effect is more compared to other forms of Nasya NOSE AND ITS ROLE IN ABSORPTION OF DRUG VIA DHUMNASYA- ${ }^{15,16}$

Nasa is said to be the main doorway to Shiras. Nasya Aushadhi reaches the brain via the nasal route and acts on higher centres of the brain controlling different neurological, endocrinal and circulatory functions and thus showing local as well as systemic effects.

The nasal route is divided into 3 functional zones: 1 . Vestibular region 2. Respiratory region 3. Olfactory region. The vestibular region is found at the opening of the nasal passage which is responsible for filtering the air coming into the nasal cavity. It is having the least important among the three regions with regards to drug absorption. Respiratory Region is mainly responsible for systemic drug absorption because it has the highest degree of vascularity. Olfactory Region plays a very important role in the transportation of drugs to the brain and CSF. The surface area of the olfactory region is about $10 \mathrm{~cm}^{2}$.

The nasal cavity is covered by a thin mucosa which is well vascular. Therefore, a drug molecule can be transferred quickly across the single epithelial cell layer directly to the systemic blood circulation without firstpass hepatic and intestinal metabolism. The effect is often reached within 5 minutes for smaller drug 
molecules. Inhalation delivers very small amounts of the medicine directly into the airway. The dose in this form is reduced to about 1/50th the dose delivered by tablet or injection.

The site of drug action i.e. Dravya and Guna Prabhava are the most complex problems in the pharmacodynamics of Ayurvedic drugs but a hypothesis can be made. The nose is the sheet of Prithvi Mahabhuta which work as a smell perception organ (Prithvi Grhanesy, Vishes Guna Gandha)

Herbal drugs use in Dhumnasya are Katu (Pungent), Tikta (Bitter) Rasaj, Ushna Virya, Laghu-TikshnaRuksha Guna, Katu-madhur Vipaka Kapha-Vata Shamaka and contain volatile oils. Most used drugs in Dhumnasya e.g. like Haridra, Guggulu, Goghrit, Devdaru, Agru, Errand etc. are having anti-inflammatory, anti-allergic, analgesic, bronchodilator and antioxidant activity Katu rasa is Vakramsodhyati (cleaning of the mouth), Agnideepyati (increasing the intensity of biological fire), Ghranamaasravyati (enhances secretion from the nose), Safutikarotiindriyanii (enhances the capacities of sense organs), Kriminihinasti (antimicrobial), Mansamvilyati (help in the dissolution of excess growth), Sonitsanghat bhinti (disintegrates the collection of clots in the blood), Marganvivrinoti (opens body channels), Slesmansamyati (restore the excess Kapha dosha in the body) whereas Tikta rasa is Vishghan (antitoxic effect), Krimighan (kills worms or parasites in the body), Lekan-Kled-meda-vasamajja-lashika-puya-swed-mutrapurish-pittasleshmaupshoshnam (can scrap the excess tissues). Langhan (gives lightness to the body), Soshan (drying up) and Sodhan (purification) are the karmas of Laghu, Ruksha and Tikshna gunas. From these descriptions, we can say that drugs used in Dhumnasya are absorbed by the epithelial layer due to Laghu guna. Ushna Virya increases the basal metabolic rate, oxygen consumption and accelerates the breakdown of fat at the mitochondrial level. According to Ayurveda, Ushna Virya helps in pacifying Kapha and Vata.

\section{CONCLUSION}

Hence, the advantages of smoke-based remedies as Dhum nasya mentioned in classics increases the bioavailability of medicines in a gaseous form which can be suggested as an effective form of drug delivery that is therapeutically efficient in curative aspects like Kasaghana dhum in Kaphaja Kasa and Kshataja Kasa when associated with Pratishyaya and Shirashool. Snaihika dum in Vataroga, Vatika Shirahshoola, Dantaharsha, Vataja Kasa, Vaiswarya (hoarseness of voice). Vrandhupan medicated fumigation to clean the wound and reduce pus formation. When looking forward to the preventive aspect of Dhum. Vamaniya Virechaniya and Prayogik Dhum are mentioned which helps to maintain the main goals of Ayurveda i.e. to preserve the health of a person by eliminating impurities, increase resistance to disease and increase harmony in life.

\section{REFERENCES}

1. http:// www. britannica. com/science/nasal insufflation [Last accessed on 2021April 5]

2. http://en.wikipwdia.org/wiki/insufflation_(medicine) [last accessed on 2021 April 5]

3. Rakesh Narayanan V: Different Therapeutic Formulations Of Nasya In Charak Samhita, International Ayurvedic Medical Journal, Volume 3; Issue 4; 1143-1148.

4. Mohagheghzadeh A., Faridi P., Shams-Ardakani M. \& Ghasemi Y. Medicinal smokes. J Ethnopharmacol 108, 161-184 (2006).

5. Nautiyal C. S., Chauhan P. S. \& Nene Y. L. Medicinal smoke reduces airborne bacteria. $J$ Ethnopharmacol 114, 446-451 (2007).

6. Shushruta Samhita, Uttartantra, Raktaabhishyandhpatished 12/6, Available from: http//niimh.nic.in/ebook/esushutra. [Last accessed on 2021 April5].

7. Charaka Samhita, Sutrasthana, Matrashitiyadhyay, 5/31-32, Available from: http//niimh.nic.in/ ebook/ echarak. [Last accessed on 2021 April5].

8. Shushruta Samhita Chikitsasthana, Dhumnasyakawalgrahachikitsitam, 40/14 Available from http//niimh.nic.in/ ebook/ esushutra. [Last accessed on 2021 April 5].

9. Charaka Samhita Chikitsasthana, Kasachikitsaadhyay, 18/48, Available from http//niimh.nic.in/ ebook/ echarak. [Last accessed on 2021 April 5].

10. Harish chandra Rajesh M et al; Study of krimighna effect of Nimbapatra as Rakshoghnadoopan by culture 
and sensitivity method WSR to Pyogenic bacteria, IRJP, 2012; 3(6):

11. Viral Kumar Patel, Alka Mishra, Vandana Shrivastava, Management of type 2 Diabetes Mellitus (T2DM) through herbal medicinal smoke (Dhoom Nasya), International Journal of yoga and allied sciences, volume 6 , issue 2.

12. Sumitha L and Prasad BS: Evaluation of Antimicrobial and Antifungal Property of Dhoopana Karma (Fumigation) - By "Dhup" An Ayurvedic Dhoopana Product. Int J Pharm Sci Res 2015; 6(7): 2950-54.DOI: 10.13040/IJPSR.0975-8232.6(7).2950-54.

13. Kajaria, Divya \& Tripathi, Jyoti \& Tiwari, S.K. (2011). Nebulization therapy - A novel approach to drug delivery system in Ayurveda. International Research Journal of Pharmacy. 2. 18-20.

14. M.Braithwaite, S.F.Van Vuuren, A.M. Viljoen,Validation of smoke inhalation therapy to treat microbial infections, Journal of Ethnopharmacology, Volume 119, Issue3, 2008, Pages 501-506 Available from: https://doi.org/10.1016/j.jep.2008.07.050

15. Raghavan, Hemang \& Bhatt, kunjal \& Satani, Kishor. (2017). Preventive, promotive and curative aspect of Dhumpana in Urdhvajatrugata Roga. Journal of Ayurveda and Integrated Medical Sciences. 2. 165-169.

16. Anuja Kumari et al: Role of Dhumpana in Nasal Pathologies. International Ayurvedic Medical Journal \{online\} 2019 \{cited January 2020\}

\section{Source of Support: Nil \\ Conflict of Interest: None Declared}

How to cite this URL: Tanuja Mehta et al: Preventive And Curative Aspect Of Dhumnasya (Nasal Insufflation Of Medicated Smoke). International Ayurvedic Medical Journal \{online\} 2021 \{cited September 2021\} Available from: http://www.iamj.in/posts/images/upload/3135 3142.pdf 